Agricultural Hall, Islington. Surgeon-Major Alexander of the Coldstream Guards, the medical offeer in charge of the troops, is assisted by Surgeon-Major Lawless, A.MI.R., and Surgeon-Lieutenant Kenneth Cameron, A.M.S.

H.R.H. the Princess Louise will open the new Headquarters of the Lordon Companies Volunteer Medical Staff Corps, Calthorp-street, and distribute ambulance prizes on on Wednesday, June 10th.

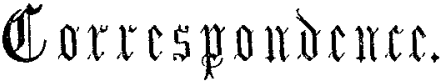

" $\Delta$ udl alteram partem."

\section{MEDICAL CERTIFICATES AND PUBLIC ELEMENTARY SCHOOLS.}

\section{To the Editors of THE LANCET.}

SIRS,--In connexion with the remarks in your issue of this week on the subject of Medical Certificates and Public Elementary Schools will you allow me to call attention to a recent departure in the practice of the Education Department which, if followed out and insisted upon, is certain to do much harm by impeding some of the most obvious and important steps which should be immediately taken in connexion with incipient epidemics of infectious disease amongst school children in rural districts? I use the term "fresh departure" advisedly, because there happens to be a larger number of separate public elementary schools in the extensive area for which $I$ act as executive medical officer of health than in the case of any other medical officer of health in Fngland and I am almost daily called upon to give certificates of some kind or other in connexion with public schools, but it is only on one or two very recent occasions that I have met with a demand for such a certificate as is referred to below. All medical officers who have had much experience in rural districts in the etiological investigation of epidemics of such diseases as diphtheria, scarlet fever, whooping-cough, and measles will agre with me that in sparsely populated districts the public school is as a rule the predominant source of infection and that in the majority of cases the dissemination takes place through mild and medically unattended cases affected so slightly as not to attract serious attention even from their parents and who either attend school personally or, if remaining at home with what is called (and often generally believed to be) merely " a cold," their brothers and sisters continue to attend school.

Medical attendance is less accessible and of necessity much more frequently done without by the working classes in rural districts than in urban districts, so that a large proportion of cases escape notification and often, after a few days' illness with "a cold and a bit of a rash or of sorethroat," children are sent back to school in response to the customary printed form of notice either to send the child or a medical certificate. Often and often when remonstrating with parents for sending children to school whom, although not medically attended, they must have known were suffering from a prevailing epidemic, I have been met with the production of the formal printed notice to send the child, also with the remarks by the mother that " the child was not bad enough to need a medical man and they were afraid of being summoned, and they thought if any harm did come through the child going to school they would not be to blame after receiving such a notice." It is in such cases as these that the cordial coöperation of a zealous and intelligent school teacher is of the utmost assistance to sanitary officials in carefully excluding all justifiably suspicious cases and all children from families where there is reason to believe any are ill with the prevailing complaint, although no medical man is in attendance. Such assistance school teachers are as a rule most anxious to afford, but their hands are already, as it is, very much tied by the regulations requiring the child's attendance or a medical certificate; but if the new departure of the Education Department is enforced they will be very much more tied, as this requires that, on counting up the number of attendances made by a child in the calculation of the daily average attendance of a school for the purpose of the grant in aid, before any allowance can be made for absence through illness under the 101st article of the code it must be shown that the child had been excluded by a special order of the sanitary authority referring separately to each child, and stating beforehand the date at which the exclusion was to commence and when it was to cease. This article in the code is not new, but the practical application of it in the way referred to in this etter is new, at least in my experience, and constitutes the new departure in practice to which I wish to direct attention. As I write this I have before me an official letter from the Education Department in which it is stated, in reference to a number of children who had been most properly excluded from school duing an epidemic of scarlet fever-either because a brother or sister was notified as suffering from scarlet fever, or some children in a house were with good reason suspected of being similarly affected but with illdefined and exceedingly mild symptoms and medically unattended, or for some other good reason on my advice as medical officer of health-that the Education Department decline to make any allowance unless it can be shown that the children were so excluded by a previous special order of the sanitary authority. Considering that to be of any service exclusion should be immediate and that as a rule sanitary authorities meet, as in the present instance, once a month only, the absurdity is too patent to merit comment. That the term "sanitary authority" is here used by the Education Department in its technical and legal sense-viz., as the sanitary council of the department-is obvious from a reference to Clauses 88 and 101 in the 1896 Education Code. Even assuming each sanitary authority to bave power to transfer its responsibility in such cases to the medical officer of health, his visiting, diagnosing, and writing orders in each individual case will involve very injurious delay, to say nothing of an enormous number of immediate and often unnecessary visits and certainly in many cases a very undesirable clashing with private roedical practitioners. In a similar case which came under my notice a few weeks ago and in which the orders for exclusion were similarly demanded by the Education Department if any allowance was to be made, the epidemic had been one of whooping-cough and only a few of the most severe cases had been medically attended. The schoolmaster had simply used his common sense and good judgment to exclude children coming from houses in which it was a matter of notoriety and an admitted fact that the children were suffering from whooping-cough.

Such unnecessary and impracticable regulations terd tcrestrict personal discretion and to cbeck the salutary zeal for the prevention of disease with which school teachers are often imbued.

I am, Sirs, yours faithfully,

W. N. THURSFTELD, M.D. Edin.

Medical Officer of Heaith for a number of Sanitary Districts in Shropshire and Seven Adjacent Counties. Shrewsbury, May 23rd, 1896.

\section{"REGISTRATION OF MIDWIVES:"}

\section{To the Editors of THE LANCET.}

Sins, - I desire to thank you for your kind and appreciative notice of my labours in connexion with this unhappy and unfortunate midwifery business.

Your wise remarks as to the necessity which exists, in view of any practical legislation, of greatly simplifying suggestions in connexion with this subject are wel? timed, and will I hope be taken to heart by the Midwives Institute and its supporters. Not only are the geese of these people all swans, but their very ducks belong to the same species. The importation by them of so exalted a body as the Privy Council into the administration of what afterall is a very humble matter, is a good example of unconscious humour and also of the fact mentioned. It reminds me of the case of the governor of a certain German castle, who was severely taken to task for having omitted to fire a Royal salute upon a necessary occasion. The poor governor gave the following reasons for his apparent neglect of duty: (1) that he had no proper artillerymen, (2) that his powder was bad, and (3) that there was not such a thing as a cannon on the premises. The last reason might have sufficed and been fairly conclusive. The Midwives Institute and its supporters have apparently plenty of cannon, although perhaps, after all, they are not very big guns and are more suitable for firing salutes than for practical warfare. They will, no doubt, learn in time that by using a simple musket they would be: 